\title{
Energy Audit of Manufacturing and Processing Industries in Nigeria: A Case Study of Food Processing Industry and Distillation \& Bottling Company
}

\author{
Oyedepo, Sunday Olayinka*, Aremu Thomas Oladele \\ Mechanical Engineering Department, Covenant University, Ota, Nigeria \\ *Corresponding author: Sunday.oyedepo@covenantuniversity.edu.ng
}

Received June 12, 2013; Revised June 20, 2013; Accepted June 21, 2013

\begin{abstract}
In this paper, analysis of the energy audit of Food processing industry and Distillation and Bottling Company in Ota, Nigeria has been carried out. A walk-through energy audit of these industries was undertaken to identify the major sources of energy in use, identifying the lapses in energy usage, identifying areas to improve energy usage, determining the level of consumption of the energy sources and recommending policy measures that will enhance energy savings in the industries and Nigerian industries at large. The study observed that among a wide variation of end-use electricity consuming equipment, electric motors were the major consumer of electrical energy, accounting for $40-47 \%$ of total electric energy. Also from the identified energy use sources in the two industries, it was observed that fuel energy expended in operating the generating set, boilers or heaters in the industries had the highest value of energy use accounting for more than $65 \%$ of the total energy used. It was observed that none of the companies under review sufficiently utilized their energy as they all have their energy used ratio far below 1 . This was as a result of some factors that contributed to energy waste and energy use inefficiency in the companies. Among these factors are: Poor in housekeeping of air- condition and refrigeration equipments and electric motors that dissipate much heat, use of electric motors that are weak and generate excessive noise because they have been rewound more than twice, improper lagging of boilers that lead to losing much heat, switching on of the lighting points in the day time and generation of electrical energy more than needed in the industry by some electric generator. The study concluded that energy is not sufficiently utilized in these companies and recommendations for efficient energy usage in the industries were proposed in this study.
\end{abstract}

Keywords: energy, efficiency, audit, electricity, industry, fuel

\section{Introduction}

Energy is an integral component of a modern economy. It is an essential ingredient in nearly all goods and services, but its use exacts heavy financial, environmental, and security costs. A key method of reducing energy's costs while retaining its benefits is to use it more efficiently.

Energy, in its different forms, is required as continuous input to all industrial processes. The total energy consumption of the industrial sectors of developed countries contributes to around $30-40 \%$ of total energy demand [1].

All over the world, energy is the key input and basic need in industrial facilities for development, economic growth, automation and modernization in the industrial sector [2,3]. However, global energy demands are increasing rapidly and this concern is addressed by international researchers on how to fulfil the future energy demand. The energy consumption was projected to increase by 33\% from 2010 to2030 in the world [4].

Energy use in the industrial sector varies widely between countries and depends principally on the level of technology used, the maturity of plants, the sector concentration, the capacity utilization and the structure of subsectors [5]. Energy use in industry is likewise heterogeneous. Each facility uses a different mix of fuels for a variety of purposes in converting raw materials into saleable products. Industries vary greatly in their overall level of energy use, because of differences in their output and energy intensity (energy use per unit of output) [6].

In the industrial sector, energy is consumed for a wide range of activities, such as processing and assembly, space conditioning, and lighting. In aggregate, the industrial sector uses more energy than any other end-use sector, consuming about one-half of the world's total delivered energy [7].

Electricity accounts for about a third of primary energy used by industries, with natural gas, petroleum, and coal accounting for about 28, 26 and 7\%, respectively [8]. Industries also use what are traditionally thought of as energy sources for non-fuel purposes. For example, industries such as chemicals and petroleum refining use crude oil, liquid propane gas (LPG), and natural gas as feed-stocks in producing products such as asphalt, gasoline, plastic resins and fertilizers. This non-fuel use of energy sources accounted for about $6.8 \mathrm{EJ}$ in 1991 [9].

Energy is one of the largest controllable costs in most organizations (especially manufacturing and processing 
industries) and there is considerable scope for reducing energy consumption and hence cost [10]. The benefits are reflected directly in an organization's profitability while also making a contribution to global environmental improvement in terms of energy conservation.

The concept of energy auditing was born shortly after the oil energy crisis in the early 1970s. Since there were many inefficient uses of energy, an auditor had a relatively easy job identifying opportunities for saving energy. Over the years, facility management become more energy conscious and as a result, energy efficiency of industrial processes increased dramatically [11]. Energy audit is a review of the total energy used and costs, normally performed in conjunction with a site investigation. It involves the classification of the energy sources and their contribution in running the factory. It provides a structural review of how energy is being purchased, managed and used with the aim of identifying opportunities for energy cost saving through improved services. It also gives the estimate of potential annual energy savings with implementation costs and pay back periods.

Energy survey is a methodical study to assess energy flows in a factory or building and establish a breakdown of the energy costs. Where performance is obviously poor, a full survey is needed.

Although Nigeria is relatively endowed with abundant fossil fuels and other renewable energy sources, the energy situation in the country is yet to be structured and managed in such a way as to ensure sustainable energy development, most especially in the industrial sector. Nigeria as a nation is passing through a serious energy crisis and it has been even more affected not by a lack of energy resources, but largely due to poor resource and financial management, a crippling dependence on imports particularly second-hand goods built with out-dated, inefficient technology etc [12]. As a nation that has limited technological capacity but sees industrialization as constituting a crucial leverage and pre-condition for meaningful development, Nigeria should be wise enough to manage her scarce energy resources judiciously.

The increasing role of energy efficiency as a catalyst for sustainable industrial development is realism in the industrialized countries of the world [13]. In Nigeria the story is different at the moment as the huge benefits derivable from adoption of energy efficiency and conservation measures by industries remain largely untapped due largely to lack of awareness of the economic and social benefits of energy efficiency measures. This, in addition to high incidence of power outages resulting to large scale use of own power generation and lack of investment capital have given rise to high specific energy content of goods produced by industries in Nigeria. The cumulative effect is loss of competitive edge in the global market by these industries and low after- tax returns. This constitutes a major disincentive to investment and sustainable industrial growth. As a matter of utmost importance, industries in Nigeria should take advantage of opportunities in low level, low risk but high worth energy efficient measures that reduces the bottom line of any business enterprise. In so doing, a lead time will be created to pursue high-tech driven production processes that will find support at maturity in an already established energy efficient culture.
The whole purpose of energy efficiency is to minimize the amount of energy used to get a desired effect. There are various principles that can be followed in energy management whose focus is the reduction of energy productivity and they include; historical energy use review, energy audits (review of current practices), thorough analysis of energy use (engineering analysis, computer simulation, availability studies, e.t.c.), aggregation of energy uses, energy conservation to mention but a few $[14,15]$.

Several studies of industrial energy efficiency in Nigeria have been performed in the last few years, and the results from the studies have been fairly consistent- that there is a readily achievable, cost-effective, reduction in industrial consumption using good energy management practices and energy-efficient equipment [16,17,18,10,19 etc].

The objectives of this study are: (i ) to examine the pattern of energy consumption in Food Processing Industry and Distillation \& Bottling Company, (ii) to identify the sources of energy waste in the selected industries and (iii) to develop appropriate strategies for effective energy savings in the industries surveyed.

\section{Methodology}

\subsection{Study Area}

The two industries surveyed in this study are located in Ota, Ogun State, Nigeria. Brief description of these industries is as follows:

\section{Case Study I - Food Processing Industry}

The Company is essentially a food processing company with a total yearly output of 24,000 tonnes of products. There are however four factories in the plant visited with each producing various products ranging from savoury seasons, tea bags, soap, detergents. The factory under consideration in this study is the savoury season factory which produces food seasoning the two products under production in this factory are seasoning 1and seasoning 2 .

Raw materials for seasoning 1 includes: salt, m.s.g., spices, h.v.p and fats while that of seasoning 2 includes salts, sugar, ribotide, flavour, fats, caramel, citric acid and water.

The main sources of energy utility for the plant are electrical, thermal and manual. The primary source of electrical energy is either from the national grid or the company's power generating set.

Power generation in this company has been contracted to external power generating company to produce electricity for the company. However, the company has six generators which include four gas generators and two diesel generators to act as standby generators. Each of these generators has a rating of 1000KVA with only three of these generators supplying electricity to the savoury season's factory and tea bags factory. It has some equipment/machines e.g. pumps, motors, boilers, chillers, compressors etc that uses electricity as their source of energy.

\section{Case Study II - Distillation \& Bottling Company}

The company produces and markets leading quality products ranging from Spirits, Dry Gin, Red Wine, Alcoholic Drinks and Non-Alcoholic Fruit Juice. The 
focus of this study is on production of non-alcoholic fruit juice.

The major sources of energy used in the factory includes: electrical, thermal (fuel) and manual energy. The Company's primary source of power supply is the Power Holding Company of Nigeria (PHCN) and 2 giant generating sets as back-up. It has some equipment/ machines e.g. pumps, motors, boilers, chillers, filler machine, capping machine, compressors etc that uses electricity as their source of energy.

\subsection{Numerical Data Collection and Analysis}

Data was collected from the industries under study through the following methods;

1. On-site study of all unit operations in the industries.

2. Structured questionnaire was administered on patterns of energy use by the selected industries for the period 2006 - 2010.

3. Oral interviews.

4. Secondary data source from the selected companies' publications (unpublished) were also used.

For the two companies under study, the following data were collected:

- Electricity, diesel, and gas consumed per annum over a 5 years period (from 2006 - 2010);

- Production rate of the Company per annum over a 5 years period (from 2006 - 2010);

- Number of occupancy/factory workers (shift) per day;

- Power rating of all machines/equipment powered by electricity

\subsection{Data Analysis}

From the data collected, the following procedural steps were taken to get them analyzed and presented in the required forms:

- Energy types (electricity and fuel) were identified and collated

- Annual consumption for each type was determined.

- The percentage breakdown of total consumption was calculated

- The energy use ratio of each company per year was determined to establish energy utilization pattern

- Energy productivity in GJ/kg was determined

- Tables and figures were prepared showing total annual consumption for each energy type for the audit period.

\subsection{Energy Evaluation:}

\subsubsection{Evaluation of Electrical energy}

The electrical energy input $E_{p}$ in kwh is obtained by multiplying the rated power of the electrical motor, $p$ in $\mathrm{kw}$ with the corresponding hours of operation $t$, the motor efficiency, $\eta$, is assumed to be $80 \%$ Fadare, et al [20]

$$
E_{p}=\eta p t
$$

$E_{p}=$ electrical energy power input $(k w h)$

$\eta=$ the motor efficiency

$t=$ hours of operation

\subsubsection{Evaluation of Thermal Energy}

The thermal energy input $E_{f}$ was calculated based on quantity of fuel used to generate steam in the boiler. The quantity of fuel $W$ in litre is converted to $\mathrm{J}$ by multiplying the quantity consumed by corresponding calorific value, $C_{f}$ of fuel.

$$
E_{f}=C_{f} W
$$

$$
\begin{aligned}
& E_{f}=\text { thermal energy input }(J) \\
& C_{f}=\text { calorific value of fuel }(\mathrm{J} / \mathrm{l}) \\
& W=\text { quantity of fuel }(w)
\end{aligned}
$$

\subsubsection{Evaluation of Manual energy}

Manual energy input, $E_{m}$ in $\mathrm{kW}$ was estimated based on the maximum continuous energy consumption rate of $0.30 \mathrm{~kW}$ and conversion efficiency of $25 \%$. According to Odigboh [21] and Norman [22], the physical power output of a normal human labour in the tropical climate is approximately $0.075 \mathrm{~kW}$ sustained for $8-10 \mathrm{~h}$ workday.

$$
\begin{aligned}
& E_{m}=0.75 N t \\
& E_{m f}=0.68 N t
\end{aligned}
$$

$E_{m}=$ manual energy input for a male worker $(k W h)$

$E_{m f}=$ manual energy for a female worker $(k W h)$

$N=$ number of persons involved in the operation

$t=$ useful time spent to accomplish a given operation $(h)$

\subsubsection{Total energy Input}

For each unit operation the total energy input is given as:

$$
E_{t}=E_{p}+E_{f}+E_{m}
$$

$E_{t}=$ total energy input

$E_{p}=$ electrical energy power input ( $\left.k w h\right)$

$E_{f}=$ thermal energy input $(J)$

$E_{m}=$ manual energy input $(k W h)$

\subsubsection{Total Energy Content (Energy Output) of Finished Product}

This total energy content of finished product was evaluated from the equation below

$$
E_{F p}=M_{f p} \times E_{C P}
$$

$E_{F p}=$ total energy content of finished goods

$M_{f p}=$ mass of finished product $(\mathrm{kg})$

$E_{C P}=$ energy content of a unit mass of product

\subsubsection{Energy Used Ratio}

Energy use ratio was evaluated as:

$$
E_{i}=\frac{E_{F p}}{E_{t}}
$$

$E_{i}=$ energy use ratio

$E_{t}=$ total energy input 
$E_{F p}=$ total energy content of finished product

\subsubsection{Energy Productivity}

This is the total energy consumed per unit production, i.e.,

$$
\text { energy productivity }=\frac{\text { Total energy consumed }(G J)}{\text { Total Production }(\mathrm{kg})}
$$

\section{Results and Discussion}

The study reveals the various unit operations carried out at the selected industries for distillation \& bottling processes and production of savoury seasons. These are depicted in Figure 1 and Figure 2 below respectively.
The results of energy usage pattern in the selected manufacturing and processing industries considered in this study are presented in this section. These data are recorded in tabular form. Table 1 and Table 2 show the annual energy consumption and production output for food processing industry and distillation \& bottling company respectively. The highest energy consumption and highest production recorded in the selected industries are 66,221GJ, 197,760 tonnes and 54,324 GJ and 128,740 tonnes respectively. These were all recorded in the year 2010. The least energy consumption and production output recorded are 52,892GJ, 39,552 tonnes and 49,271 GJ, 108,960 tonnes respectively. These were recorded in the year 2006 .

The summaries of the percentage total energy consumed for the five years period for the selected industries are given in Table 3 and Table 4.

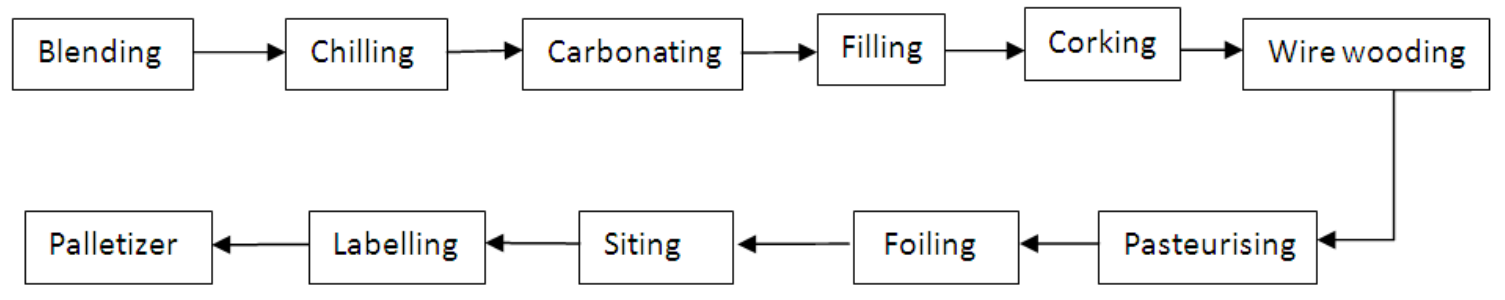

Figure 1. Typical flow diagram for producing non-alcoholic drinks

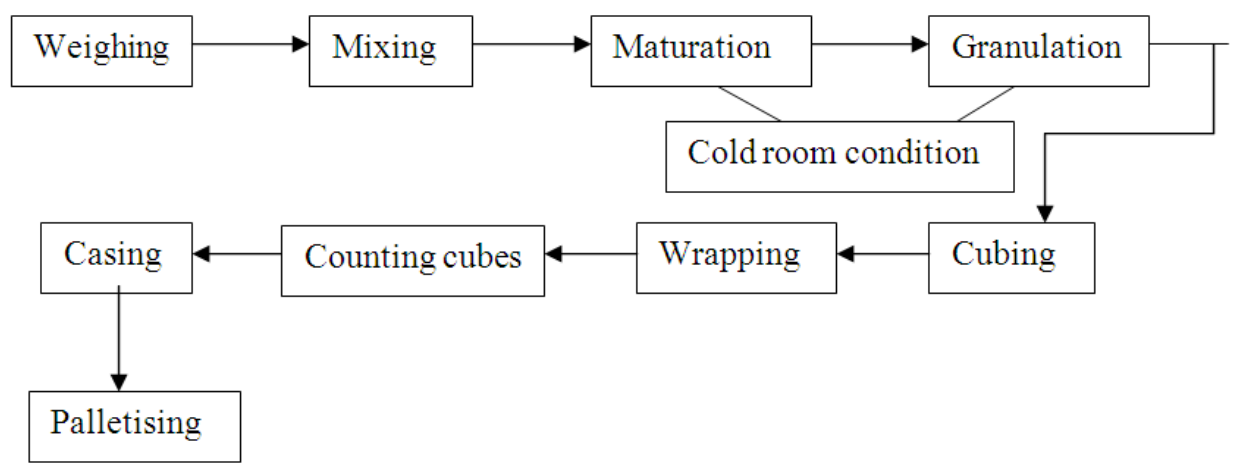

Figure 2. Production diagram for Savour Seasoning Powders

Table 1. Annual energy consumption and production output for Food Processing Industry

\begin{tabular}{|c|c|c|c|c|c|c|c|c|c|c|}
\hline \multirow[t]{3}{*}{ Year } & \multicolumn{9}{|c|}{ Energy Sources } & \multirow[t]{3}{*}{$\begin{array}{l}\text { Production } \\
\text { (tonnes) }\end{array}$} \\
\hline & \multicolumn{2}{|c|}{ Electricity } & \multicolumn{2}{|c|}{ Diesel } & \multicolumn{2}{|c|}{ Gas } & \multicolumn{2}{|c|}{ Manual } & Total & \\
\hline & kWh & GJ & Vol.(ltr) & GJ & MSCF & GJ & No & GJ & GJ & \\
\hline 2006 & 3539227.7 & 12,731 & 72356 & 2729 & 29703.36 & 36,508 & 152 & 924 & 52,892 & 39,552 \\
\hline 2007 & 4172009.5 & 15,007 & 73425 & 2769 & 30026.49 & 36,906 & 162 & 985 & 55,667 & 99,100 \\
\hline 2008 & 4311579.4 & 15,509 & 75863 & 2861 & 32097.67 & 39,451 & 166 & 1009 & 58,830 & 128,656 \\
\hline 2009 & 4303254.5 & 15,479 & 76960 & 2902 & 34488.58 & 42,390 & 172 & 1046 & 61,817 & 158,208 \\
\hline 2010 & 4505931.9 & 16,208 & 80090 & 3020 & 37382.83 & 45,947 & 172 & 1046 & 66,221 & 197,760 \\
\hline
\end{tabular}

Table 2. Annual energy consumption and production output for Distillation \& Bottling Company

\begin{tabular}{|c|c|c|c|c|c|c|c|c|c|c|}
\hline \multirow[t]{3}{*}{ Year } & \multicolumn{9}{|c|}{ Energy Sources } & \multirow[t]{3}{*}{$\begin{array}{c}\text { Production } \\
\text { (tonnes) }\end{array}$} \\
\hline & \multicolumn{2}{|c|}{ Electricity } & \multicolumn{2}{|c|}{ Diesel } & \multicolumn{2}{|c|}{ Heavy fuel oil } & \multicolumn{2}{|c|}{ Manual } & Total & \\
\hline & kWh & GJ & Vol.(ltr) & GJ & Vol.(ltr) & GJ & No & GJ & GJ & \\
\hline 2006 & 671830 & 2417 & 909567.4 & 34,300 & 238674 & 9,781 & 358 & 2773 & 49,271 & 108,960 \\
\hline 2007 & 688714 & 2477 & 934567.0 & 35,243 & 245600 & 10,065 & 363 & 2812 & 50,597 & 117,620 \\
\hline 2008 & 657894 & 2367 & 964660.0 & 36,377 & 261500 & 10,716 & 364 & 2819 & 52,279 & 118,400 \\
\hline 2009 & 667544 & 2401 & 970803.6 & 36,609 & 273000 & 11,188 & 370 & 2866 & 53,064 & 120,960 \\
\hline 2010 & 675163 & 2429 & 1012493.0 & 38,181 & 264000 & 10,819 & 374 & 2895 & 54,324 & 128,740 \\
\hline
\end{tabular}


Table 3. Summary of the percentage of total energy consumed for Food processing industry

\begin{tabular}{|c|c|c|c|c|c|c|}
\hline \multirow[t]{2}{*}{ Energy Source } & \multicolumn{5}{|c|}{ Total Energy Consumed (\%) } & \multirow[t]{2}{*}{ Average(2006 - 2010) } \\
\hline & 2006 & 2007 & 2008 & 2009 & 2010 & \\
\hline Electricity & 24.07 & 26.96 & 26.36 & 25.04 & 24.48 & 25.38 \\
\hline Diesel & 5.16 & 4.97 & 4.86 & 4.69 & 4.56 & 4.85 \\
\hline Gas & 69.02 & 66.30 & 67.06 & 68.57 & 69.38 & 68.07 \\
\hline Manual & 1.75 & 1.77 & 1.72 & 1.69 & 1.58 & 1.70 \\
\hline
\end{tabular}

Table 4. Summary of the percentage of total energy consumed for distillation \& bottling company

\begin{tabular}{|c|c|c|c|c|c|c|}
\hline \multirow[t]{2}{*}{ Energy Source } & \multicolumn{5}{|c|}{ Total Energy Consumed (\%) } & \multirow[t]{2}{*}{ Average(2006 - 2010) } \\
\hline & 2006 & 2007 & 2008 & 2009 & 2010 & \\
\hline Electricity & 4.90 & 4.90 & 4.53 & 4.52 & 4.47 & 4.66 \\
\hline Diesel & 69.60 & 69.70 & 69.58 & 68.99 & 70.28 & 69.63 \\
\hline Heavy fuel oil & 19.85 & 19.89 & 20.50 & 21.08 & 19.91 & 20.25 \\
\hline Manual & 5.63 & 5.56 & 5.39 & 5.40 & 5.33 & 5.46 \\
\hline
\end{tabular}

Table 3 shows that manual energy expended in operating machines and lifting of loads was found to be the least consumer of energy accounting for $1.7 \%$ (on average)of the total energy input on for the 5 years period of study. The gas fuel energy was expended in operating gas generator and was the highest energy consumer and on average it accounted for $68 \%$ of the total energy input for the years studied. Table 4 shows the summary of the percentages of total energy consumed in distillation \& bottling company for the period of five years of study. Contrary to Table 3, the least energy consumed was electricity from National grid (i.e from National grid) accounting for $4.66 \%$ on average. Reason for this might be as a result of epileptic nature of power supply from Power Holding Company Nig. Plc (PHCN). Diesel fuel energy expended in operating diesel engine was the highest consumed source of energy and it accounted for $69.6 \%$ on average.

Patterns of electrical energy consumption by various industrial equipment used for different stages of operation at food processing industry is depicted in Figure 3. Wrapping process accounted for highest electrical energy consumption (80\%) counting machine accounted for $0.2 \%$ of total electrical energy consumed in the production line.

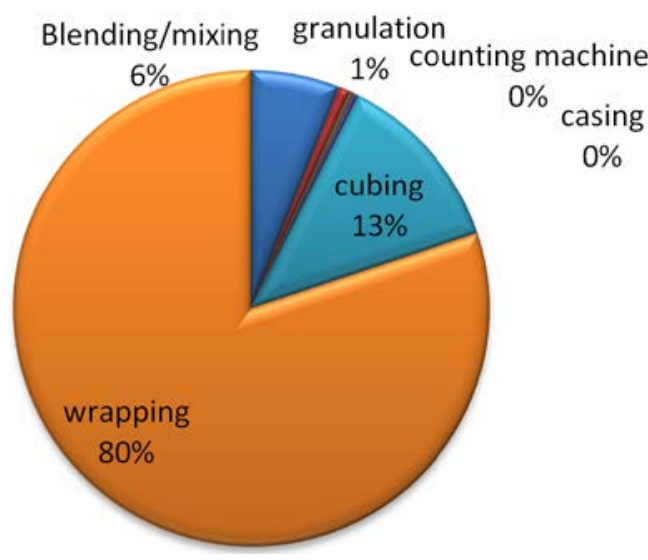

Figure 3. Percent of electrical energy consumed by electric motors various processes at food processing industry

Oven consumed highest percentage of electrical energy at distillation and bottling company (Figure 4). It accounted for $49 \%$ of total electrical energy consumed. The least electrical energy consumer is palletizer and it accounted for $0.094 \%$ of total electrical energy consumed in the production line.

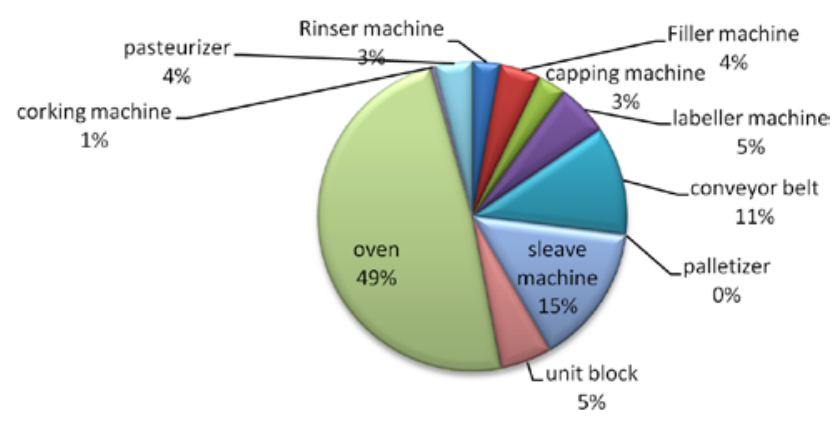

Figure 4. Percent of electrical energy consumed by electric motors for various processes at distillation \& bottling company

Figure 5 and Figure 6 show electrical energy consumption pattern of electrical appliances and equipments available in the industries surveyed. Out of 120.60 GJ of energy consumed in every production at food processing industry, electrical motor accounted $40 \%$ of total energy consumed (Figure 5) while lightning accounted for $2 \%$ as the least electrical energy consumer. Figure 6 shows electrical energy consumed in percentage by electrical appliances and equipments in distillation and bottling company. Electrical motor also accounted for highest energy consumer (49\%) and the least is standing fan $(0.36 \%)$.

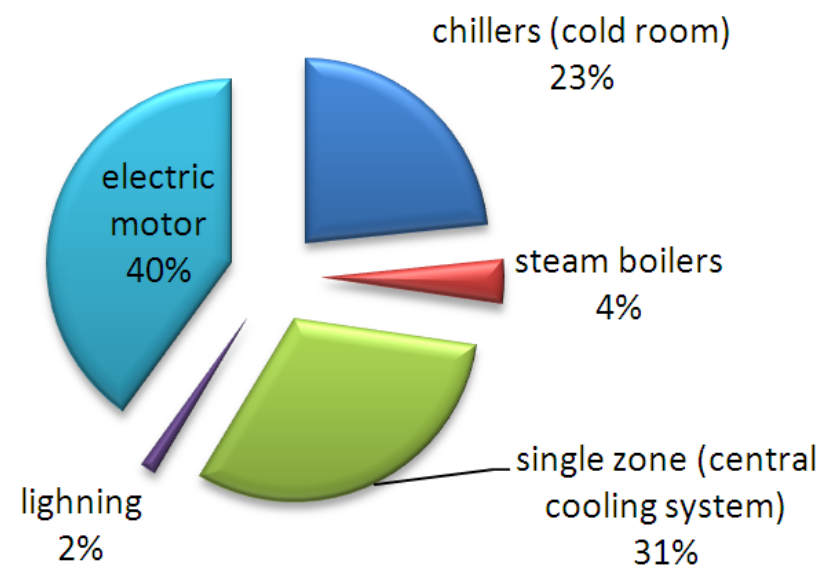

Figure 5. Percent energy consumed by various electrical appliances and equipments at food industry 


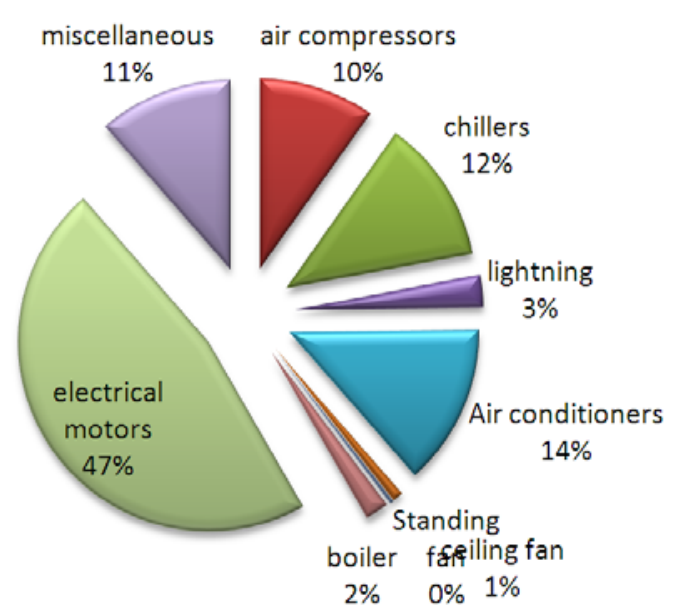

Figure 6. Percent energy consumed by various electrical appliances and equipments at distillation and bottling company

The energy productivity and energy used ratios for the period of five years $(2006$ - 2010) for the two industries under consideration are shown in Figures $7-10$. The energy productivity at food industry was $1.34 \mathrm{GJ} / \mathrm{kg}$ in 2006 and decreased to $0.33 \mathrm{GJ} / \mathrm{kg}$ in 2010. Energy used ratio varied from 0.019 to 0.079 . Highest value was recorded in 2006 and the least value was recorded in 2007. At distillation and bottling company, energy productivity varied from $0.42 \mathrm{GJ} / \mathrm{kg}$ to $0.45 \mathrm{GJ} / \mathrm{kg}$. Highest value was recorded in 2006 and the least value was recorded in 2010. Energy used ratio had highest value of 0.063 in 2007 and the least value of 0.060 in 2006. In these two industries surveyed, the energy used ratios within the period of study are less than unit. This indicates ineffective utilization of energy in the industries. This implies that more energy is expended in unit production of finished product. High proportion of energy input is wasted to the factory floor.

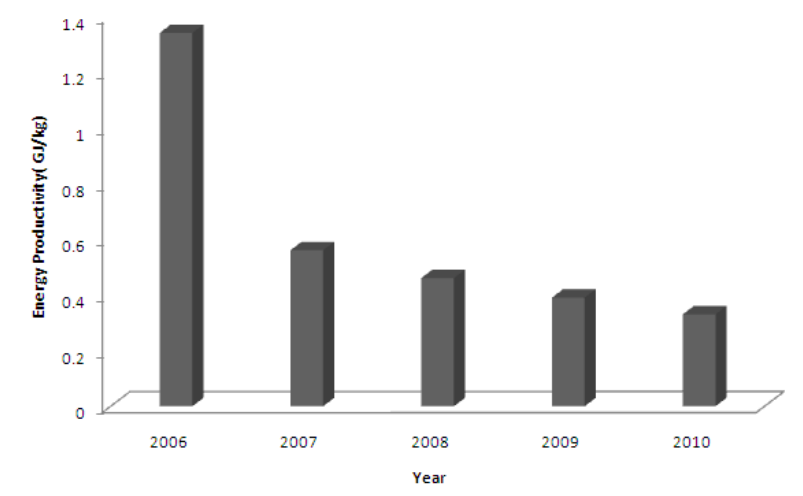

Figure 7. Energy productivity for period of 5 years $(2006-2010)$ at Food Processing Industry

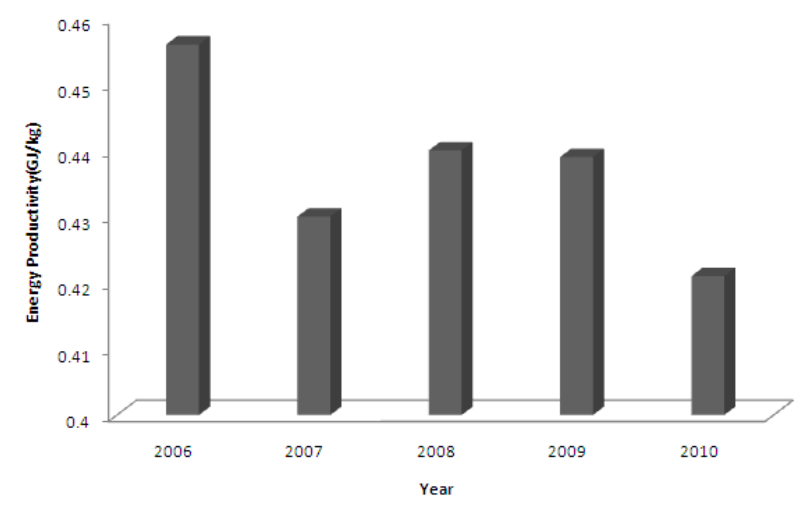

Figure 8. Energy productivity for period of 5 years $(2006-2010)$ at Distillation \& Bottling Company

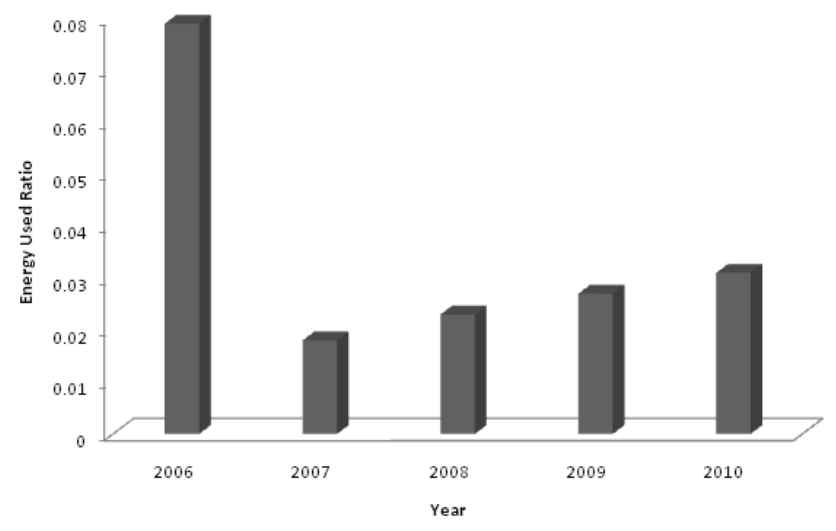

Figure 9. Energy Used Ratio for Period of 5 years $(2006$ - 2010) at Food Processing Industry

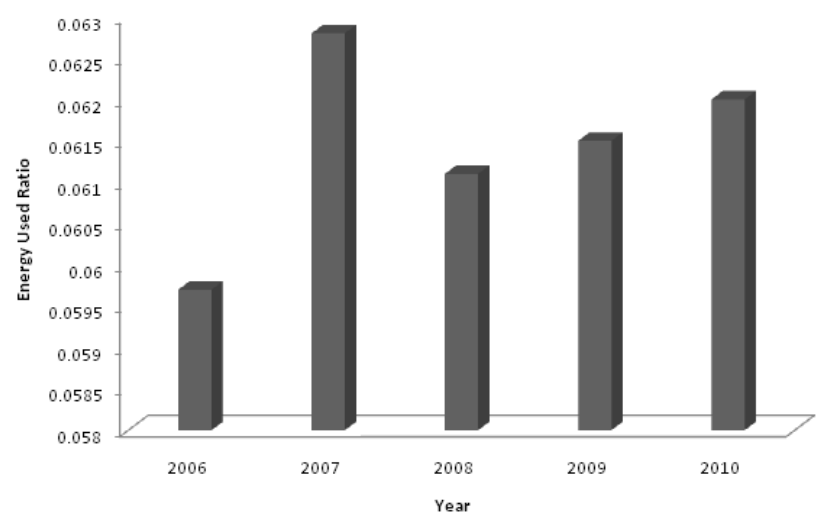

Figure 10. Energy Used Ratio for Period of 5 years $(2006$ - 2010) at Distillation\& Bottling Company

\subsection{General Observations}

One of the aims of the walk-through audit is to identify bad practices, inefficient equipment and poor energy habit in order to save power consume. From walk-through energy audit carried out at the food processing industry and distillation \& bottling company, energy saving opportunities in the following sections was observed:

- Heating, Ventilation and air- conditioning (HVAC) System

Heating, ventilating, and air-conditioning (HVAC) is an important use of energy in the industrial sector. The environmental needs in an industrial operation can be quite different from residential or commercial operations.

At the two industries surveyed, it was observed that aircondition and refrigeration equipments were dirty and dissipating much heat. It was also observed that there was no minimum temperature setting for air conditioners and refrigerators so that staff can use it for regulating their temperatures.

In these industries, energy can be saved if:

i. The heat exchangers are regularly cleaned for easy heat transfer.

ii. They are not placed in direct access to sunlight or heat dissipating objects.

iii. Cooling temperatures are set for the entire company to avoid wastage.

iv. Doors should be fitted with springs to allow for selfcontrol to trap cold air.

v. Consider the provision of fresh air of constant temperature in the factory by the installation of a new 
ventilation system using a rotary heat exchanger. The warm exhaust air heats the incoming air in the exchanger. The temperature is controlled by the number of revolutions of the exchanger

\section{- Electrical Drives}

Electric drives of one type or another use $68 \%$ of industrial electricity. Examples include electric motors, machine tools, compressors, refrigeration systems, fans, and pumps. Improvements in these applications would have a significant effect on reducing industrial electrical energy.

It was observed at the industries visited that some electric motors are weak and generate excessive noise because they have been rewound more than twice. Also, it was observed that some of the motors were dirty, dusty and poorly ventilated.

Some energy can be saved by:

i. Reconfiguring electrical motors from delta to star connection which will make it run at less than $33 \%$ of the rated output.

ii. Replacement of old electric motors with new ones

iii. Proper house- keeping and operation of electric drives. Good ventilation reduces energy loss to heating

iv. Install variable speed drives and soft-start options on electric Motors

\section{- Electric Process Heat}

Electricity is widely used as a source of process heat due to ease of control, cleanliness, wide range in unit capacities (watts to megawatts), safety, and low initial cost. Typical heating applications include resistance heaters (metal sheath heaters, ovens, furnaces, boilers), electric salt bath furnaces, infrared heaters, induction and highfrequency resistance heating, dielectric heating, and direct arc electric furnaces.

In these industries surveyed, boilers were observed to be losing much heat because they are not properly lagged. Energy can be saved in these industries by:

i. Replacement of ageing boilers with new and much smaller boilers to reduce energy wastage.

ii. Considering investing in high-precision burner controls for continuous correct air-fuel ratio management

iii. Considering recovery of flash steam from condensate and consider using the recovered low-pressure steam elsewhere

iv. Proper lagging of pipes carrying steam from boilers to the factory so as to reduce heat lost to the environment.

\section{- Lighting}

Industrial lighting uses about $20 \%$ of electrical energy and $7 \%$ of all energy. Of all lighting energy about $20 \%$ is industrial, with the balance being sizes of systems, energy management opportunities in industrial lighting systems are similar to those in residential/commercial systems.

During the walk-through, it was observed that some of the lighting points were on even though the sunlight was bright enough to provide illumination. Energy consume through lighting can be reduced by:

i. Providing electronic control to conserve daytime power waste for lighting. Energy conservation of the order of $10 \%$ can be achieved by making arrangement to switch off lights automatically when not required.

ii. Replacing lower-efficiency lighting with more efficient (or energy saving) types (e.g., mercury lamps with HP sodium lamps) and replace all standard fluorescent tubes with high-efficiency tubes ( $T^{*}$ series). iii. Painting the factory walls and ceilings with white or lighter colours and use the light reflectance to improve the brightness of the workplace.

\section{- Electric Generator}

In the course of walk-through energy audit, it was observed the electric generator used at distillation and bottling company generate energy more than needed in the industry. This results in energy (i.e fuel) wastage and high cost of production. Energy wastage can be reduced by:

i. Considering getting smaller generator for load shedding as this will minimize energy wastage

ii. Replacing diesel generator to gas generator. As gas is cheaper, cleaner and burns readily in air.

\subsection{Recommendations}

Based on the discussion and data from the audit report from industries surveyed, the following can be recommended as measures to conserve energy:

i. Retrofit of all the 4-feet fluorescent and incandescent lamps with Compact Fluorescent Lamps CFLs.

ii. Put spring mechanism on the door of rooms with A/Cs for unmanned closing of the doors.

iii. Switching off most lighting during day time.

iv. Reduce steam leakages along pipelines and improve lagging of steam pipes;

v. Install electric meters in major production and administrative units to monitor/curtail power wastages in each unit thereby reducing energy cost on power

vi. Significant capital investment should be made in replacement of inefficient energy consuming equipment to reduce the energy consumption

vii. Motivation for energy conservation among workers

From the study a number of important policy implications are implicit. These include:

- High energy cost has adversely affected employment situation in the industry. Retrenchment of workers/reduction in number of shifts is always an easier way of reducing cost than other options such as energy efficiency;

- Energy reduction is another substitute for job reduction and both companies and government as well as development partners should be actively engaged in industrial energy efficiency options in developing countries, like Nigeria;

- In these companies' plants, many machines are very old and thus do not meet the highest energy efficiency standard;

- In these companies, lots of heat energy are generated as by-products but are not being reused at other parts of the plants but simply thrown away;

- National benchmarks for energy consumption in the various industrial processes are not available;

- Possibility of joint production of power by companies is there but such independent power generation depends on reliable gas supply and competitive energy prices;

- Need for case studies and concrete measures which can be followed by companies to become more energy efficient. In other words, technological advice on energy efficient options will be very useful;

- The need to help in developing cases for small and medium scale power plants and providing information about industrial energy-use; 
- Finance for investment in energy efficiency not readily available either from retained earnings or bank loans due mainly to the financial crisis; and

- Need for incentives or subsidies on investments in energy efficiency. Since companies pay fine for polluting the environment with generators, they should be rewarded for greening the environment with energy efficient machines/processes.

- Just like the National Agency for Food, Drug Administration and Control, (NAFDAC) empowered to check all food and drug that are imported to the country and even to have a say on what comes to Nigeria from their primary place of production overseas, both governmental and non-governmental engineering bodies/organizations should be empowered alongside with Standard Organization of Nigeria (SON), Council for the Regulation of Engineering in Nigeria (COREN) by the Nigeria government to formulate and implement policies to promote energy conservation and efficiency in Nigerian industries in general.

\section{Conclusions}

This research work examined the pattern of energy consumption in food processing industries and distillation \& bottling company in Ota, Nigeria; identified the sources of electrical energy waste and assessed the effectiveness of the strategies for electrical energy savings in the industries.

The sources of energy in the industries surveyed comprise of manual, fossil fuel (diesel and gas) and electricity (from National grid). The pattern of electrical energy consumption in the companies investigated was mainly from generating set; this was due to either low voltage or epileptic power supply from national grid. For the period of five years (2006 -2010), the percentage of electric energy consumed (from National grid) is $25.38 \%$ for food industry and $4.66 \%$ for distillation \& bottling company. Whereas, percentage of fossil fuel consumed is $68.07 \%$ (Gas) for food industry and 69.6\% \& 20.25\% (diesel and heavy oil respectively) for distillation and bottling company. The areas where the industries surveyed use and waste energy, and where actions for energy conservation can be implemented have been identified. Energy use lapses identified in this study were due to lack of good energy conservation practices (such as replacing worn out engine parts), diesel leakage, steam leakage from steam pipeline and ageing of machines/equipment.

The results of the analysis made over the five years period show that energy was not efficiently utilized at the companies surveyed. In food processing industry, the energy productivity decreased substantially from 1.34GJkg-1 in 2006 to $0.33 \mathrm{GJkg}-1$ in the year 2010. An average of 59,085.4 GJ of energy was consumed annually within this period with an average production of $124,655.2$ tonnes. The energy used ratio varied from 0.0187 (in 2007) to 0.079 (in 2006). In distillation and bottling company, the energy productivity decreased substantially from $0.456 \mathrm{GJkg}-1$ in 2006 to $0.421 \mathrm{GJkg}-1$ in the year 2010. An average of 51,907 GJ of energy was consumed annually within this period with an average production of 118,936 tonnes. The energy used ratio varied from 0.0597 (in 2007) to 0.0628 (in 2006). Based on the energy used ratio, it shows that none of these industries utilize energy effectively as the energy ratio computed is less than unit.

In order to curtail unnecessary wastage of energy and to reduce cost of energy consumption, the following factors must be critically looked into:

- Procurement of test equipment for energy monitoring in the factory.

- Significant capital investment to improve the energy consumption

- Detailed audit to identify the causes of energy wastes.

- Proper maintenance and control must be done in order to improve the energy productivity.

\section{References}

[1] Morvay, Z.K and Gvozdenac, D.D (2008), Applied Industrial Energy and Environmental Management, IEEE Press, John Wiley and Sons, Ltd, Publication, United Kingdom.

[2] Saidur R, Hasanuzzaman M, Sattar M. A, Masjuki H. H, Irfan Anjum M and Mohiuddin A.K. M (2007), 'An analysis of energy use, energy intensity and emissions at the industrial sector of Malaysia', International Journal of Mechanical Materials Engineering, 2(1):84-92.

[3] 3. Hasanuzzaman M, Saidur R and Masjuki H.H (2011), 'Effects of different variables on moisture transfer of household refrigerator-freezer', Energy Education Science and Technology Part A-Energy Science and Research 27(2):401-18.

[4] Abdelaziz E.A, Saidur R and Mekhilef S (2011), 'A review on energy saving strategies in industrial sector', Renewable \& Sustainable Energy Reviews, 15(1): 150-68.

[5] McKane, A, Price, L and Stephane C (2008), Policies for Promoting Industrial Energy Efficiency in Developing Countries and Transition Economies, United Nations Industrial Development Organization (UNIDO), Vienna.

[6] U.S. Congress, Office of Technology Assessment (1993), Industrial Energy Efficiency, OTA-E-560 Washington, DC: U.S. Government Printing Office.

[7] International Energy Outlook (2011), U.S Energy Information Administration.

[8] Energy Information Administration (EIA) (1995) Annual Energy Review 1994 U.S. Department of Energy, Energy Information Administration, Washington, DC.

[9] Energy Information Administration (EIA) (1994) Manufacturing Consumption of Energy 1991 U.S. Department of Energy, Energy Information Administration, Washington, DC.

[10] Jekayinfa, S.O (2006) "Energy Consumption Pattern of Selected Mechanized Farms in Southwestern Nigeria" Agricultural Engineering International: the CIGR E-journal, Manuscript EE 06 001, Vol. VIII. April.

[11] Mitrovic, B and Muller, M.R (2002), 'Energy Impacts of Productivity Improvements In Manufacturing', Proceedings from the Twenty-fourth National Industrial Energy Technology Conference, Houston, TX, April 16-19.

[12] Eleri, E.O (1995), 'Nigeria: Energy for Sustainable Development', Volume 19, Number 1, Journal for Energy and Development, 104.

[13] Davidson, O (2006), 'Energy for Sustainable Development: An Introduction'. In: Winkler, $\mathrm{H}$ (Ed.), Energy Policies for Sustainable Development in South Africa, Option for the Future.

[14] Eastop, T.D and Croft, D.R (1990), Energy Efficiency, Addison Wesley Longman Limited, England.

[15] Payne, G.A (1997), The energy manager's handbook. IPC Science and Technology Press Ltd, UK.

[16] Noah, O.O, Obanor, A.I and Audu, M. L (2012), 'Energy Audit of a Brewery-A Case Study of Vitamalt Nig. Plc, Agbara', Energy and Power Engineering, 4, 137-143.

[17] Aiyedun, P.O; Adeyemi, O.A and Bolaji, B.O (2008), ‘Energy Efficiency of a Manufacturing Industry: A Case Study Of Nigeria Eagle Flour Mills Limited, Ibadan', ASSET Series B 7 (2):91-103

[18] Goshwe, N.Y and Kureve, T.D (2012), 'Industrial Energy Management Opportunities in Nigeria: A Case Study of Energy Audit of VIK Industries Nigeria, Ltd', The Pacific Journal of Science and Technology, 13(1) May (Spring), pp 152-168. 
[19] Aderemi, A.O, Ilori, M.O, Aderemi, H.O and Akinbami, J.F.K (2009): Assessment of electrical energy use efficiency in Nigerian food industry. African Journal of food Science vol 3(8) pp. 206216.

[20] Fadare,D.A; Nkpubre, D.O; Oni, A.O; Falana, A; Waheed M.A and Bamiro, O.A (2010), "Energy and Exergy Analyses of Malt Drink Production in Nigeria," Energy, Vol. 35, No. 12, 2010, pp. 5336-5346.
[21] Odigboh E.U (1998), ‘Machines for crop production’, In: Stout B. A, editor, CIGR handbook of agricultural engineering, American Society of Agricultural Engineers.

[22] Norman, M.J.T. (1978), 'Energy Inputs and Outputs of Subsistence Cropping Systems in the Tropics', Agro-Ecosystems, 4: 355-366. 